\title{
Growth of white clover seedlings treated with aqueous extracts of leaf and root of tough lovegrass
}

\author{
Adriana Favaretto ${ }^{1}$, Simone Meredith Scheffer-Basso ${ }^{1,2}$, Vanderleia Felini ${ }^{1}$, Alana Neto \\ Zoch $^{1}$, Cercí Maria Carneiro ${ }^{1}$
}

1 Universidade de Passo Fundo.

2 Bolsista de Produtividade CNPq.

\begin{abstract}
This study was carried out to investigate the effect of extracts of leaf and roots of tough lovegrass (Eragrostis plana) on seedling growth of white clover (Trifolium repens), in two experiments. The first experiment was conducted as a pilot test, in which two concentrations (30 and 60\%) of leaf aqueous extract were tested. In Experiment II, source (leaf/root) and concentration (5 and 10\%) of the extracts were combined. Distilled water was used as control in both trials. Fifty seedlings at 7 days of age were placed in gerbox containers on filter paper moistened with extracts and incubated at $25^{\circ} \mathrm{C}$ for 14 days. In the first experiment, percentage of normal seedlings decreased by $82.5 \%$ and $100 \%$ at the concentrations of $30 \%$ and $60 \%$, respectively, which indicated the need to increase the dilution of the extracts. In the subsequent experiment, the extracts from the two sources, at $10 \%$ of concentration, reduced by $78 \%$ the percentage of normal seedling and increased the percentage of abnormal seedlings, which reached $27 \%$. At $5 \%$ concentration, the leaf extract was the most deleterious treatment, resulting in greater mortality $(\mathrm{M}=27.6 \%)$ and abnormality $(\mathrm{A}=19.5 \%)$ of seedlings, compared to the root extract $(\mathrm{M}=4.8 \% ; \mathrm{A}=9.5 \%)$ and the control $(\mathrm{M}=2.4 \% ; \mathrm{A}=0.25 \%)$. The morphological changes caused by the extracts were radicle necrosis, retention of cotyledons and absence of secondary roots. The results suggest that allelopathic compounds from leaves and roots of tough lovegrass differ in chemical nature and/or concentration.
\end{abstract}

Key Words: allelophaty, abnormal seedlings, dead seedlings

\section{Crescimento de plântulas de trevo-branco tratadas com extratos aquosos de folha e raiz de capim-annoni-2}

RESUMO - Este estudo foi realizado para investigar o efeito do extrato de folhas e raízes de capim-annoni-2 (Eragrostis plana) no crescimento de plântulas de trevo-branco (Trifolium repens), em dois experimentos. O primeiro experimento foi conduzido como teste-piloto, no qual foram testadas duas concentrações ( $30 \%$ e $60 \%$ ) de extrato aquoso de folhas. No experimento II houve uma combinação de fonte (folhas e raízes) e concentração (5\% e 10\%) dos extratos. Água destilada foi utilizada como testemunha em ambos os ensaios. Cinqüenta plântulas com sete dias de idade foram colocadas em caixas gerbox, sobre papel-filtro umedecido com os extratos, e incubadas a $25^{\circ} \mathrm{C}$ durante 14 dias. No primeiro experimento, o percentual de plântulas normais decresceu em $82,5 \%$ e $100 \%$ nas concentrações de $30 \%$ e $60 \%$, respectivamente, o que indicou a necessidade de se aumentar a diluição dos extratos. No experimento subseqüente, os extratos das duas origens, a $10 \%$ de concentração, reduziram em $78 \%$ o percentual de plântulas normais e aumentaram o percentual de plântulas anormais, que atingiu 27\%. A $5 \%$ o extrato de folha foi o tratamento mais deletério, resultando em maior mortalidade $(\mathrm{M}=27,6 \%)$ e anormalidade ( $\mathrm{A}=19,5 \%)$ de plântulas, comparado ao de raiz $(M=4,8 \% ; A=9,5 \%)$ e à testemunha $(M=2,4 \% ; A=0,25 \%)$. As alterações morfológicas causadas pelos extratos foram necrose da radícula, retenção dos cotilédones e ausência de raízes secundárias. Os resultados sugerem que os compostos alelopáticos de folhas e raízes do capim-annoni-2 diferem quanto à natureza química e/ou concentração.

Palavras-chave: alelopatia, plântulas anormais, plântulas mortas

\section{Introduction}

Tough lovegrass (Eragrostis plana Nees.) is the most aggressive weed in natural pastures in southern Brazil. Its control is difficult because of the easy dissemination, low nutritional quality and acceptance, highly competitive growth, drought resistance and allelopathic effect (Abichequer et al., 2006; Coelho, 1986; Medeiros \& Focht, 2007) of this plant.

Coelho (1986) observed inhibition on seed germination and seedling development of white clover (Trifolium repens $\mathrm{L}$.) cultivated in soil from an area invaded by tough 
lovegrass for ten years, and no adverse effect of root and aerial part extracts on plant growth was observed. Alcoholic extracts of roots and leaves have shown a very strong effect on seed germination of white clover (Coelho, 2000). Ferreira et al. (2008) verified depressed effect on seed germination of Paspalum notatum Flügge, $P$. regnellii Mez, Setaria sphacelata Schumach and Megathyrsus maximus Jacq. when the seeds were covered with stem and leaf fragments of tough lovegrass (Ferreira et al., 2008).

The leaves and roots are the major sources of allelochemicals and their release to environment occur by leaching, volatilization, root exudation and degradation of fragments of dead and decaying plant material (Favoretto, 1993). Leigh et al. (1995) showed that mulched residues from Phalaris aquatica and Triticum aestivum L. reduced the germination and production of Trifolium subterraneum L.

A limited number of works has been conducted about the allelopathic effect of aqueous extracts of tough lovegrass on white clover seedlings. The objectives of the current study were to determine (1) whether aqueous extracts from leaves and roots of tough lovegrass have the same allelopathic effect on seedling growth, and (2) what the morphological changes caused by the allelopathic extracts are.

\section{Material e Methods}

Extracts were prepared with leaves and roots from nonflowering tough lovegrass plants, which were presented at the edge of a field. The plants were separeted into leaf and root parts and $100 \mathrm{~g}$ of each one were washed, cut into small pieces and dryed in a forced oven air at $60^{\circ} \mathrm{C}$ for seven days. Subsequently, the material was soaked in $1.000 \mathrm{~mL}$ of boiled distilled water for thirty minutes, filtered and evaporated in a rotary evaporation. After complete drying, the gross mass was determined in an analytical scale and the standard stock solutions were prepared at $2.73 \mathrm{~g} / \mathrm{mL}$ concentration and $\mathrm{pH}=5.5$. The stock solutions were diluted with distilled water to give the different concentrations to be tested. The extracts were stored at $4^{\circ} \mathrm{C}$ before being applied to seedlings.

Two experiments were carried out: firstly, only leaf extracts at 0,30 and $60 \%$ concentration were tested as a pilot test. Subsequentely, a second experiment evaluated different sources (root and leaf) and concentrations (0, 5 and 10\%) of extracts. In both trials, distilled water was used as control and the experimental design was completely randomized, with four replications. Fifty sedlings of white clover at seven days of age were placed on filter paper treated with $5 \mathrm{~mL}$ of extracts in gerbox containers and incubated at $20^{\circ} \mathrm{C}$ in the growth chamber for 14 days (Brasil, 2009). Two more applications of $2 \mathrm{~mL}$ extracts were necessary to keep the substrate moisture. The dead, abnormal and normal seedlings were recorded on the $4^{\text {th }}, 10^{\text {th }}$ and $14^{\text {th }}$ day after the first extract application. According to Brasil (2009), abnormal seedlings show damage in their essential structures and a weak development.

Treatment effects and days-of-observation were analyzed with repeated-measures ANOVA, the averages were compared by Tukey test and a regression analysis was carried out to identify the relationship between seedling response and day-of-observation. The software SISVAR was used (Ferreira, 2000).

\section{Results and Discussion}

The Experiment I revealed that 30 and $60 \%$ concentrations were markedly toxic, reducing the percentage of normal seedlings by 86.5 and $100 \%$, respectively, on the $10^{\text {th }}$ day (Table 1). No normal seedling was found in these treatments on the $14^{\text {th }}$ day. Both concentrations caused the maximum percentage of abnormal seedlings on the $10^{\text {th }}$ day and total mortality on the $14^{\text {th }}$ day. In contrast, the control treatment showed the presence of abnormal seedlings only on the $14^{\text {th }}$ day.

The results indicated the necessity to change the concentrations to allow a higher time of seedling survival because the seedling development stage must be long enough to classify them as normal or abnormal (Brasil, 2009). Also, Coelho \& Schmidt (2001) suggested that extract high concentration should be avoided in allelopathic studies because of the reduction of water potential and difficulty in interpretation results. As for tough lovegrass there is still no protocol for studies on allelopathy but the type of the extracts, aqueous or alcoholic, can influence the results. Kruse et al. (2000) do not recommend the use of organic solvent and address the importance to identify the allelochemicals if a physiologically based protocol is to be followed.

In Experiment II, the effect of concentration on seedling growth during the incubation time was dependent on the extract source (Figure 1). The root and leaf extract at 10\% concentration caused a pronounced decrease on normal seedlings, but at $5 \%$, the effect of root extract was less severe than leaf extract effects. The differential effects may be due to the presence of higher proportion of active allelochemicals in the leaf than the root and/or different chemical nature. The higher mortality caused by leaf extract at $5 \%$ compared to the root extract at the same concentration strengthens this hypothesis (Figure 2). 
Table 1 - Normal, abnormal and dead seedlings of white clover treated with aqueous leaf extract of tough lovegrass at three concentrations over time

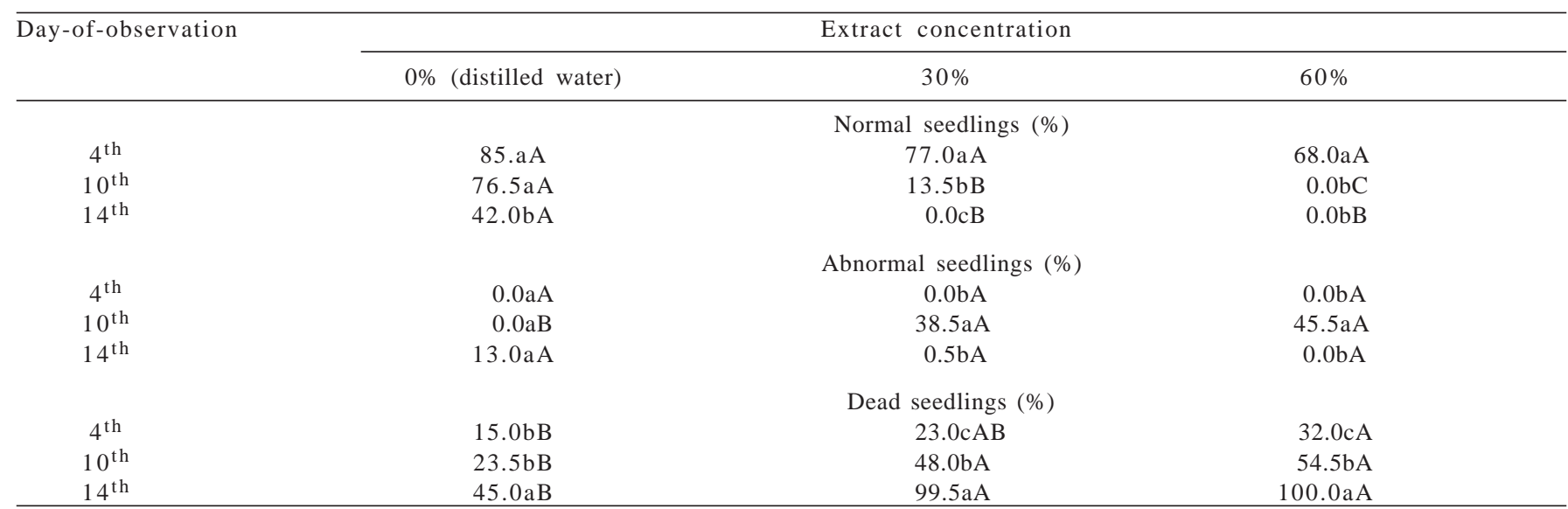

Averages followed by the same letter, capital letter in the row and lowercase letter in the column, do not differ (P>0.05) by Tukey test.

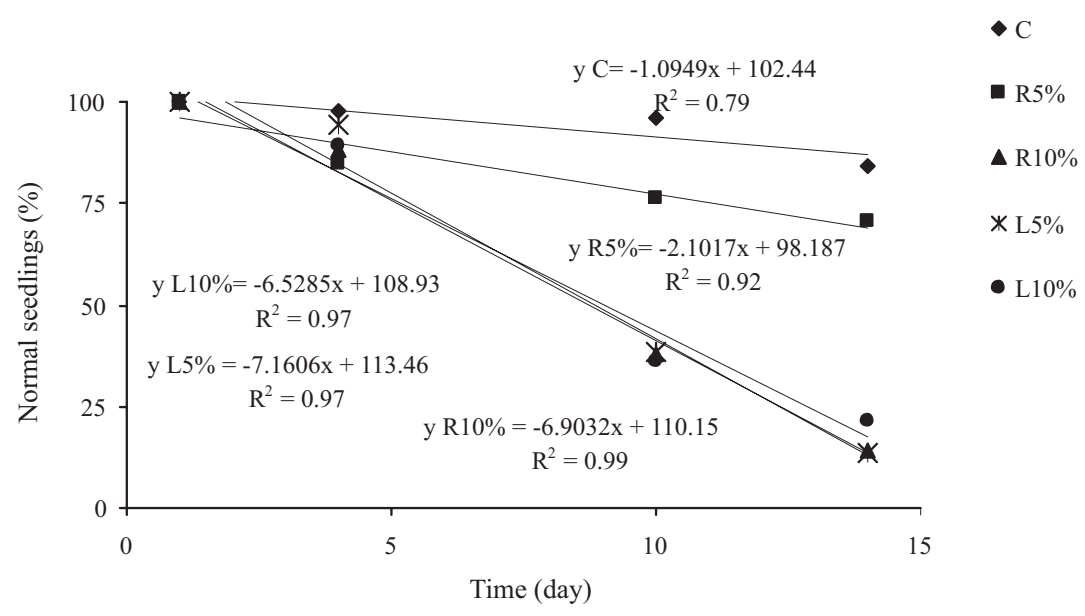

Figure 1 - Percentage of white clover normal seedlings treated with leaf (L) and root (R) aqueous extract of tough lovegrass over time. (C= control, distilled water).

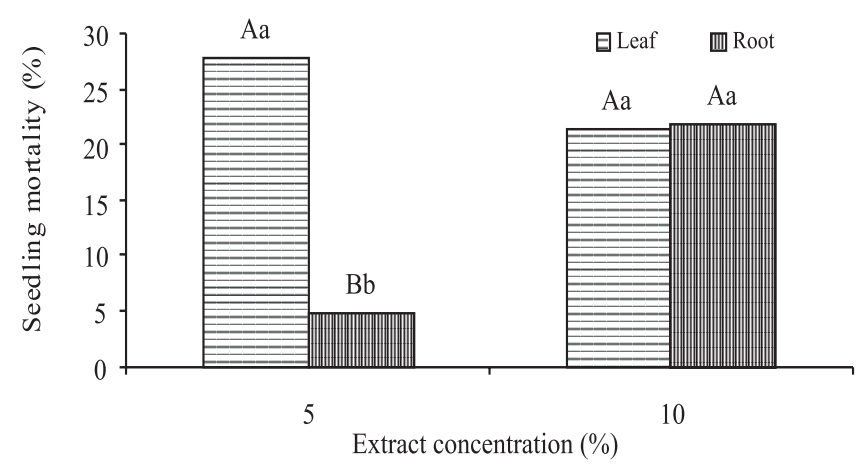

Figure 2 - Seedling mortality percentage of white clover treated with leaf and root aqueous extract of tough lovegrass.

The same letter (capital letter compare the concentration in the same source and lower case letter comparing the source in the same concentration) indicates similarity $(\mathrm{P}>0.05)$ by Tukey test.
The present findings corroborate the earlier reports about the toxicity level depending on the part of the plant used. In the study of Sisodia \& Siddiqui (2010), allelochemical content was higher in leaves than in stems of Croton sp. Pereira et al. (2008) observed that leaf extract of alfalfa (Medicago sativa L.) was more toxic to the seedlings of the same culture compared to the root extract. Also, Chon \& Kim (2002) verified that leaf extract of this leguminous was more effective at depressing the root and hypocotyl growth and that the main allelochemicals (coumarin, transcinnamic acid and 0-coumaric-acid) were not present in root samples. Chung \& Miller (1995) reported higher inhibition of alfalfa seedling growth when exposed to flower and leaf extracts when compared to the root one. 
The extracts caused morphological changes in seedlings, as evidenced from the $4^{\text {th }}$ day. On the $10^{\text {th }}$ day, the differences between treatments became more pronounced, when it was recorded the highest percentage of abnormal seedlings (Figure 3). The leaf and root extracts at $10 \%$ resulted in $19.5 \%$ of abnormal seedlings compared to $9.5 \%$ observed with the root extract at $5 \%$ concentration. On the $14^{\text {th }}$ day, when the seedlings were 21 days of age, no differences were observed between 5 and 10\% concentration ( $p>0.05$ ), because most seedlings was dead.

The abnormalities observed in seedlings were radicle necrosis, absence of secondary roots and coat presence in seeds after germination. The radicle necrosis is a common allelopathic symptom(Ferreira, 2004). Souza Filho et al.(1997) stated the interference on radicle growth is one of the best indicators for evaluating the allelopathic effect.

The present study provides evidence that allelopathic effect of tough lovegrass varies with the part of plant, which indicates the importance to test aqueous extracts from inflorescences, stems and seeds, as well as their different phenological stage (for example, green and senescent leaves). Information on the relationship between allelopathic action and quantity and/or residual decomposition of this species on the sward can support management practices. The mowing and sowing of the desirable forages in natural pastures could occur when the more allelopathic component is present in small quantity.

This considerations are supported by several reports, which state that allelopathy action is mainly important when vegetation residues are on the soil surface (Kotnik \& Vidrih, 2002). Actually Ferreira et al. (2008) found higher adverse effect on seed germination of forage grasses as long as the coverage level with fresh fragments of tough lovegrass was increased. As the fast-germinating species were not damaged, it is believed that allelochemicals were released during the decomposing of residues. Wardle et al. (1993) proposed that nodding thistle (Carduus nutans L.) is allelopathic to pasture grasses and legumes at two phases of its development, i.e. at the early bolting stage when the larger rosette leaves are decomposing and releasing soluble inhibitors, and at the stage when bolting plants are drying and releasing insoluble inhibitors.

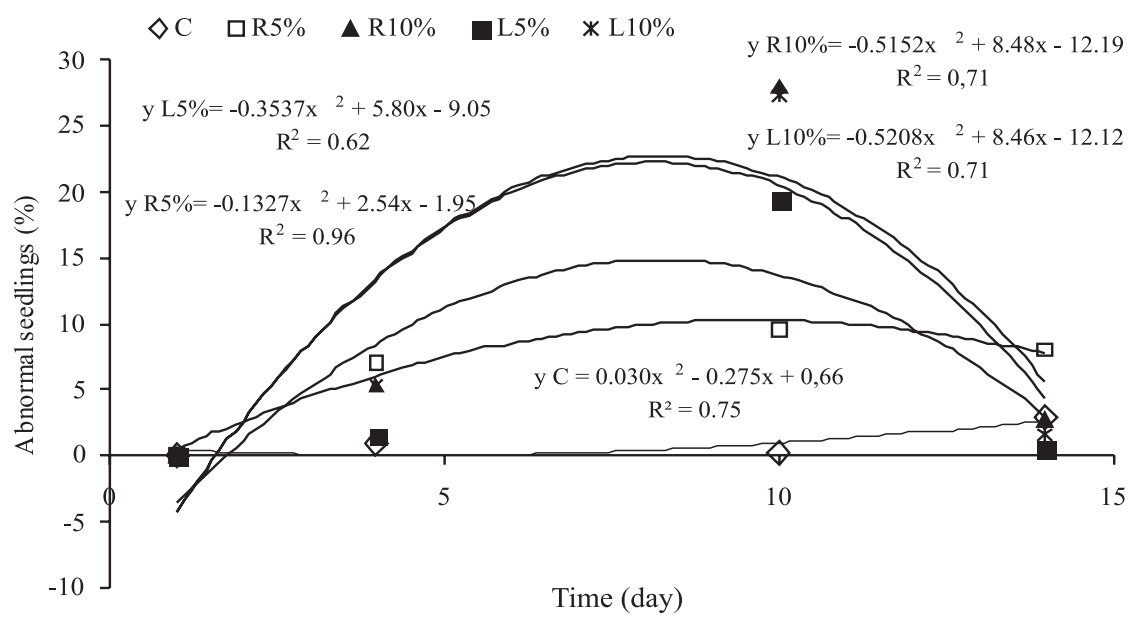

Figure 3 - Abnormal seedling percentage of white clover treated with leaf (L) and root (R) aqueous extract of tough lovegrass over time. $(\mathrm{C}=$ control, distilled water).

\section{Conclusions}

Leaf aqueous extract of tough lovegrass is more allelopathic on white clover seedlings than root extract, suggesting that allelochemicals differ in chemical nature and/or concentration. Radicle necrosis, coat seed presence and secondary root absence are the main toxicity symptoms of the tough extracts on seedlings of this leguminous.

\section{References}

ABICHEQUER, A.D.; MEDEIROS, C.M.O.; SPANNENBERG, P.R.O. Crescimento e distribuição de raízes de capim-annoni-2: vantagem competitiva em relação ao campo nativo? In: REUNIÃO DO GRUPO TÉCNICO EM FORRAGEIRAS DO CONE SUL, 21., 2006, Pelotas. Palestras e Resumos... Pelotas: Embrapa Clima Temperado, [2006]. (CD-ROM).

BRASIL. Ministério da Agricultura, Pecuária e Abastecimento. Regras para análise de sementes. Brasília: MAPA, ACS, 2009. 399p. 
CHON, S.U.; KIM, J.D. Biological activity and quantification of suspected allelochemicals from alfalfa plants parts. Journal of Agronomy and Crop Science, v.188, n.4, p.281-285, 2002.

CHUNG, I.M.; MILLER, D.A. Effect of alfalfa plant and soil extracts on germination and growth of alfalfa. Agronomy Journal, v.87, n.4, p.762-767, 1995.

COELHO, R.W. Efeito alelopático em Eragrostis plana, um problema ecológico no sul do Brasil. Agropecuária Clima Temperado, v.3, n.1, p.69-74, 2000.

COELHO, R.W. Substâncias fitotóxicas presentes no capim-annoni2. Pesquisa Agropecuária Brasileira, v.21, n.3, p.255-263, 1986.

COELHO, R.W.; SCHMIDT, R.E. Allelopathic influence of Eragrostis curvula water extract on seed germination and seedling growth of two other species. In: INTERNATIONAL GRASSLAND CONGRESS, 19., 2001, São Paulo. Proceedings... São Paulo: International Grassland Society, 2001. Disponível em: <http://www.internationalgrasslands.org/publications/pdfs/ id0106.pdf $>$. Acesso em: 10/6/2010.

FAVORETTO, V. Adaptações de plantas forrageiras ao pastejo. In: SIMPÓSIO SOBRE ECOSSISTEMAS DE PASTAGENS, 2., 1993, Jaboticabal. Anais... Jaboticabal: FUNEP, 1993. p.1-17.

FERREIRA, D.F. Análises estatísticas por meio do Sisvar para Windows versão 4.0. In: REUNIÃO ANUAL DA REGIÃO BRASILEIRA DA SOCIEDADE INTERNACIONAL DE BIOMEtriA, 45., 2000. São Carlos. Anais... São Carlos: UFSCAR, 2000. p.255-258.

FERREIRA, A.G. Interferência: competição e alelopatia. In: BORGHETTI, F. (Ed.) Germinação: do básico ao aplicado. Porto Alegre: Artmed, 2004. p.251-262.

FERREIRA, N.R.; MEDEIROS, R.B.; SOARES, G.L. Potencial alelopático de capim-annoni-2 (Eragrostis plana Nees) na germinação de sementes de gramíneas estivais. Revista Brasileira de Sementes, v.30, n.2, p.43-50, 2008.
KOTNKIK, T.; VIDRIH, T. Influence of some herbaceous species on germination and early growth of white clover. In: FISHER, G.; FRANKOW-LINDBERG, B. (Eds.) Lowland and grasslands of Europe: utilization and development. Roma: FAO, 2002. Disponível em: <http://www.fao.org.> Acesso em: 10/2/2011.

KRUSE, M.; STRANDEBERG, M.; STRANDERGERG, B. Ecological effect of alelopathic plants - a review. Silkeborg, Dennmark: National Environmental Research Institute, 2000. 66p. (Techical Report, 315)

LEIGH, J.H.; HALSALL, D.M.; JOLGATE, M.D. The role of allelopathy in legume decline in pastures. I. Effects of pasture and crop residues on germination and survival of subterranean clover in the field and nursery. Australian Journal of Agricultural Research, v.46, n.1, p.179-188, 1995.

MEDEIROS, R.B.; FOCHT, T. Invasão, prevenção, controle e utilização do capim-annoni-2 (Eragrostis Plana Nees) no Rio Grande do Sul. Pesquisa Agropecuária Gaúcha, v.13, n.1-2, p.105-114, 2007.

PEREIRA, B.F.; SBRISSIA, A.F.; SERRAT, B.M. Alelopatia intraespecífica de extratos aquosos de folha e raízes de alfafa na germinação e no crescimento inicial de plântulas de dois materiais de alfafa: crioula e melhorada. Ciência Rural, v.38, n.2, p.561-564, 2008.

SISODIA, S.; SIDDIQUI, M.B. Allelopathic effect by aqueous extracts of different parts of Croton bonplandianum Baill. on some crop and weed plants. Journal of Agricultural Extension and Rural Development, v.2, n.1, p.22-28, 2010.

SOUZA FILHO, A.P.; RODRIGUES, L.R.A.; RODRIGUES, T.J.D. Efeitos do potencial alelopático de três leguminosas forrageiras sobre três invasoras de pastagens. Pesquisa Agropecuária Brasileira, v.32, n.2, p.165-170, 1997.

WARDLE, D.A.; NICHOLSON, K.S; RAHMAN, A. Influence of plant age on the allelopathic potential of nodding against. Weed Research, v.33, n.1, p.69-78, 1993. 